\title{
Health Benefits of Cornelian cherry (Cornus mas L.)
}

\author{
Zeliha Kaya ${ }^{1(\mathbb{D})}$, Ikay Koca ${ }^{2(\mathbb{D})}$ \\ ${ }^{1}$ Department of Food Engineering, Faculty of Engineering, Giresun University, Giresun, Turkey \\ ${ }^{2}$ Department of Food Engineering, Faculty of Engineering, Ondokuz Mayıs University, Samsun, Turkey
}

Copyright@ Author(s) - Available online at https://dergipark.org.tr/en/pub/mbsjohs

Content of this journal is licensed under a Creative Commons Attribution-NonCommercial 4.0 International

License,

Received: 16 November 200, Accepted: 25 March 2021, Published online: 30 April 2021

(C) Ordu University Institute of Health Sciences, Turkey, 2021

\begin{abstract}
Medicinal plants have been used for medical objectives since ancient times due to their beneficial properties, and their uses continue to this day. The Cornelian cherry fruit (Cornus mas L.) is considered to be one of those medicinal plants with important nutritional and therapeutic properties. It has been also used for different medical purposes in many countries in Europe and Asia for centuries due to its various important components in terms of health. Cornelian cherry is known to have antimicrobial, antioxidant, anticancer and antiinflammatory effects due to its composition of phenolic compounds and ursolic acid. It is reported in the literature that This fruit is used in different countries for different purposes; for the treatment of intestinal and kidney diseases, strengthening immunity, and preventing some types of cancer and others. It is also used in traditional medicine to cure fever, cholera, kidney stones, malaria, urinary tract infections, heat stroke and bleeding. Many studies have reported the positive effect of Cornelian cherry in regulating blood sugar and preventing fat accumulation in the liver. Similar to many countries, it is grown in Turkey in many regions and it is consumed processed or fresh into several crops such as compote, jam, marmalade and fruit leather. This paper has reviewed the investigative studies of the health effect of cornelian cherry.
\end{abstract}

Keywords: Medicinal plants; Cornellian cherry; antioxidant; antimicrobial; health benefit.

Suggested Citation: Kaya Z, Koca I. Health Benefits of Cornelian cherry (Cornus mas L.). Mid Blac Sea Journal of Health Sci, 2021; 7(1):154-162

\section{Address for correspondence/reprints:}

Zeliha Kaya

Telephone number: $+90(543) 3800824$

E-mail: zeliha_mol@hotmail.com 


\section{Introduction}

In recent years, interest in fruits rich in antioxidant compounds has increased with the emergence of the relationship between food and health. Cornelian cherry is one of the fruits that grow naturally in Turkey. This fruit is a rich source of phenolic compounds, anthocyanin, and ascorbic acid. It has been reported in the literature that it has antibacterial, antihistamine, antiallergic, antimicrobial, antimalarial and anti-diabetic properties due to its antioxidant properties (1). Cornelian cherry fruits can be consumed dried or fresh as well as processed into marmalade, jam and fruit juice.

It is known that many factors such as developing technology, increasing environmental pollution, used pesticides, smoking and alcohol use, Ultraviolet (UV) rays, and work and living conditions all increase the stress level. These environmental and psychological factors cause the formation of free radicals in humans and the increase of the resulting radicals can trigger various diseases. These highly reactive radicals damage the cell membrane and biomolecules found in the cell structure such as proteins, enzymes, lipids, carbohydrates and nucleic acids. In some cases, the body's defense mechanism is insufficient to fight against these radicals and the oxidative stress arises in the human body (2). Oxidative stress can be a cause of aging, cancer, cardiovascular diseases, lung diseases, diabetes and cataracts. The elimination of these factors adversely affecting human health is thought to prevent the formation of such diseases and protect human life (3).

\section{General taxonomy information and distribution}

The genus Cornus L. from the Cornaceae family consists of 65 known species that grow mostly in the form of trees and bushes. Cornus L. species are widely grown in the northern hemisphere, mostly Anatolia, the Caucasus and Europe (1). Among the Cornus species found in different parts of Asia and Europe, four species are known to have edible fruits, namely Cornus officinalis, C. mas, C. kousa and C. controversa (4). Cornelian cherry is a type of fruit that grows on trees with a stem diameter of $25-45 \mathrm{~cm}$, which can grow up to 7-8 meters in height, or bush that shed its leaves in winter.

Cornelian cherry is a type of stone fruit. It ripens in late summer and early autumn. This fruit is an elliptical-shaped, 10-15 mm long, pink-red colored, slightly sour, tasty and nutritious fruit $(5,6)$. Average fruit weight is between 5-8 $\mathrm{g}$ and kernel constitutes $7.5-11 \%$ of whole fruit weight. In wild-growing species, the yield is between 2.8 and $4.8 \mathrm{~kg}$ per bush, while with ideal rain and sun intake, this amount can reach up to $10 \mathrm{~kg}$ per bush. A yield of $30-80 \mathrm{~kg}$ per plant can be obtained in agriculturally grown species (6).

\section{Phytochemical Composition}

It is reported that Cornelian cherry fruit contains up to $88 \%$ of water, and it is a wealthy source of organic acids, vitamin $\mathrm{C}$, proanthocyanidin, anthocyanin, epicatechin, and catechin (7). This fruit has an impressive red color due to the anthocyanin compounds that contain. They also contain phenolic compounds which have very beneficial effects on health. The diverse phytochemicals found in different parts of Cornelian cherry are summarized in Table 1.

The participants with UI were evaluated in terms of quality of life. Comparisons of the participants with different types of UI are presented in Table 2A,B. Mixed incontinence patients exhibited the least satisfaction in quality of life compared to both urge and stress incontinence in our study. According to UDI-6 total and subscale scores, patients with stress incontinence were in more discomfort than patients with urge incontinence. The same results were obtained with IIQ-7 total and subscales (Table 2A,B).

Cornelian cherry contains plenty of phenolic compounds, anthocyanin, and ascorbic acid. The fresh fruit contains $101-193 \mathrm{mg} / 100 \mathrm{~g}$ ascorbic acid (19), 223-292 mg/100g total anthocyanin expressed as cyanidin-3-O-glycoside (1) and 281-704 mg/100g total phenolic compounds (20). Anthocyanins are the most important phenolic compounds of this fruit, followed by other flavonoids, phenolic acids and tannins, respectively. The leaves are richer in phenolic compounds $(11.30 \%)$ when compared to fruits. Although the leaves contain more flavonoids, they contain no anthocyanins (10). Besides, the flowers are rich source of phenolic compounds, especially flavonoids (21).

Cornelian cherry is usually consumed fresh, as jam, compote, marmalade and pestle. Recently, this fruit got interestingly importance in pharmaceutics since it contains many neutraceuticals. It displays a sour taste, since it has a high level of vitamin $\mathrm{C}$. The juice is 10 -fold richer in calcium than pear, plum and apple juices. The juice contains also an important level of Fe, Mn, Zn, Na, and K (22). It was reported that Cornelian cherry could be used for prevention remedy of coronary heart diseases and cancer thanks to its bioactive compounds. Furthermore, it exhibits antioxidant and inflammatory properties due to its high level of phenolic compounds and ursolic acid (1). 
Table 1. The diverse phytochemicals found in different parts of cornelian cherry

\begin{tabular}{|c|c|c|c|}
\hline $\begin{array}{l}\text { Phytochemical } \\
\text { group }\end{array}$ & Part of plant & Chemical constituents & References \\
\hline Flavonoids & $\begin{array}{l}\text { Fruits, flowers and } \\
\text { leaves }\end{array}$ & $\begin{array}{l}\text { aromadendrin 7-O- glucoside, } \\
\text { aromadendrin 7-O- xyloside, } \\
\text { aromadendrin 7-O- glucoside, } \\
\text { trans-Aromadendrin, } \\
\text { kaempferol 3-O-galactoside, } \\
\text { kaempferol 3-O-glucuronide } \\
\text { quercetin, quercetin 3-O-xyloside, } \\
\text { quercetin 3-O-rhamnoside, } \\
\text { quercetin 3-O- galactoside, } \\
\text { quercetin 3-O-rutinoside, } \\
\text { quercetin 3-O-glucoside } \\
\text { quercetin 3-O-robinobioside } \\
\text { quercetin 3-O-galactosyl 7-O-rhamnoside } \\
\text { myricetin, naringenin 3-O-methyl ester } \\
\text { 7,3'-dihydroxy-5,4'-dimethoxyflavanone, } \\
\text { 4-acetoxy-5,2',4',6'- } \beta \text { - pentahydroxy-3- } \\
\text { methoxychalcone, isorhamnetin 7-O- } \\
\text { rhamnoside }\end{array}$ & $(8-12)$ \\
\hline Flavanols & Fruits and leaves & (+) -Catechin, (-) -epicatechin & (10) \\
\hline Anthocyanins & Fruits & $\begin{array}{l}\text { cyanidin 3-O-robinobioside, } \\
\text { cyaniding 3-O-galactoside } \\
\text { cyanidin 3-O-glucoside, } \\
\text { cyanidin 3-O-rutinoside, } \\
\text { delphinidin 3-O- } \beta \text {-galactopranoside, } \\
\text { delphinidin-3-O-galactoside } \\
\text { delphinidin 3-o-rutinoside } \\
\text { pelargonidin 3-O-rutinoside, } \\
\text { pelargonidin 3-O-glucoside, } \\
\text { pelargonidin 3-O-galactoside } \\
\text { pelargonidin 3-O-robinobioside } \\
\text { pelargonidin 3-O- glucoside, } \\
\text { peonidin 3-O-glucoside chloride. }\end{array}$ & $(1,9,11,13)$ \\
\hline $\begin{array}{l}\text { Phenolic acids and } \\
\text { tannins }\end{array}$ & Fruits and flowers & $\begin{array}{l}\text { ellagic acid, gallic acid, quinic } \\
\text { acid, shikimic acid,chlorogenic acid } \\
\text { 5-O-caffeoylquinic acid } \\
\text { 3-O-caffeoylquinic acid, } \\
\text { ferulic acid,vanillic acid } \\
\text { salicylic acid, p-coumaric acid }\end{array}$ & $(10,14-16)$ \\
\hline İridoids & Fruits & $\begin{array}{l}\text { Loganin, loganic acid, } \\
\text { cornuside, sweroside }\end{array}$ & $(13,16)$ \\
\hline Carotenoids & Fruits & $\begin{array}{l}\beta \text {-Carotene, } \\
\beta \text {-carotene-5,6-monoxide, } \\
\text { lutein-5,6-epoxide, lutein, luteoxanthin } \\
\text { (13Z, 13'Z)-lutein, }\left(9 Z, 9^{\prime} Z\right) \text {-lutein, } \\
\text { (9'Z)-neoxanthin, (all-E)-neoxanthin, }\end{array}$ & (17) \\
\hline Fatty acids & Fruits and leaves & $\begin{array}{l}\text { Linoleic acid, oleic acid, } \alpha \text {-linolenic acid, } \\
\text { palmitoleic acid, palmitic acid, stearic } \\
\text { acid,2,4-heptadienoic acid }\end{array}$ & $(15)$ \\
\hline Organic acids & Fruits and leaves & $\begin{array}{l}\text { oxalic acid, maleic acid, isocitric acid, } \\
\text { malonic acid, , succinic acid, tartaric acid, } \\
\text { citric acid, fumaric acid }\end{array}$ & $(9,15)$ \\
\hline Vitamins & Fruits & $\begin{array}{l}\text { Ascorbic acid, } \alpha \text {-tocopherol, biotin, } \\
\text { riboflavin }\end{array}$ & (18) \\
\hline
\end{tabular}


Table 2A. Beneficial effects of different parts of Cornelian cherry

\begin{tabular}{|c|c|c|c|}
\hline $\begin{array}{l}\text { Activity } \\
\text { tested }\end{array}$ & $\begin{array}{l}\text { Plant } \\
\text { part }\end{array}$ & Effect & Reference \\
\hline \multirow[t]{6}{*}{ Antioxidant } & fruits & $\begin{array}{l}\text { Fruit extracts displayed important antioxidant } \\
\text { activities and the FRAP value was } 21-57.8 \text { FRAP } \\
\text { units. }\end{array}$ & (20) \\
\hline & $\begin{array}{l}\text { Leaves, } \\
\text { flowers }\end{array}$ & $\begin{array}{l}\text { The methanol extracts from leaves, flowers and fruit } \\
\text { showed acceptable antioxidant activity and the } \mathrm{IC}_{50}\end{array}$ & $(21)$ \\
\hline & and fruits & $\begin{array}{l}\text { value was } 39.40,27.58 \text { and } 251.87 \mu \mathrm{g} / \mathrm{mL} \\
\text { respectively. }\end{array}$ & \\
\hline & Fruits & $\begin{array}{l}\text { All extracts displayed significant antioxidant activities } \\
\text { with FRAP unit of } 190-200 \mu \mathrm{M} / \mathrm{g} \text { in FRAP assay and } \\
\text { IC } 50 \text { of } 3.95-9.67 \mathrm{mg} \mathrm{mL} \text { in DPPH assay. }\end{array}$ & (14) \\
\hline & fruits & Showed good antioxidant activity with & $(31)$ \\
\hline & & $\begin{array}{l}1509-5954 \mu \mathrm{molFe}^{2+} / 100 \mathrm{~g} \text { FRAP assay, } 623- \\
1903 \mu \mathrm{mol}_{\mathrm{TE}} / 100 \mathrm{in} \text { DPPH assay and } 441- \\
1475 \mu \mathrm{mol}_{\mathrm{TE}} / 100 \mathrm{~g} \text { in ABTS assay, }\end{array}$ & \\
\hline \multirow[t]{3}{*}{ Antimicrobial } & $\begin{array}{l}\text { Fruits, } \\
\text { leaves }\end{array}$ & 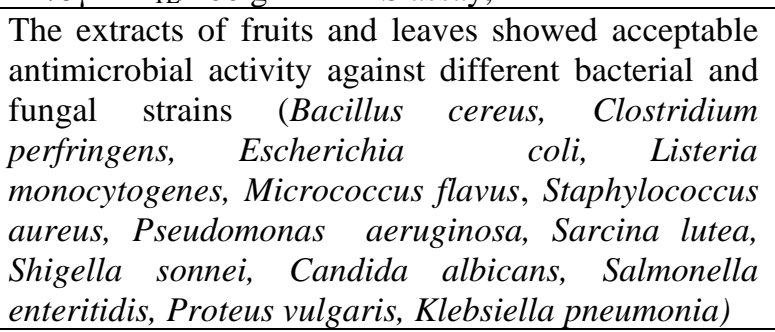 & (10) \\
\hline & fruits & $\begin{array}{l}\text { Showed significant antimicrobial activity against } \\
\text { Pseudomonas aeruginosa and Staphylococcus aureus. } \\
\text { The extract was killed them all in one week and there } \\
\text { was no bacterial growth until the 28th day. }\end{array}$ & (32) \\
\hline & fruits & $\begin{array}{l}\text { The most efficient antibacterial effect was enounced } \\
\text { by water and methanol extract of CM fruit against } \\
\text { Staphylococcus aureus the Minimum Inhibitory } \\
\text { Concentration value was value } 0.156 \mathrm{mg} / \mathrm{ml} \text { and } \\
\text { inhibition zone was } 25 \mathrm{~mm} \text { ) and just methanol extracts } \\
\text { showed an antifungal effect. }\end{array}$ & (33) \\
\hline \multirow[t]{4}{*}{ Anti-diabetic } & Fruits & $\begin{array}{l}\text { It was observed to reduce high levels of low-density } \\
\text { lipoprotein cholesterol (LDL-C), (aspartate) AST, } \\
\text { triglycerides (TG), alanine aminotransferase (ALT) } \\
\text { and alkaline phosphatase (ALP) to normal levels. }\end{array}$ & (34) \\
\hline & Fruits & $\begin{array}{l}\text { After } 6 \text { weeks of intervention, significant increase in } \\
\text { insulin as well as decrease in } \mathrm{HgbA}_{1} \mathrm{C} \text { and } \mathrm{TG} \text { levels }\end{array}$ & (35) \\
\hline & & $\begin{array}{l}\text { was seen in the drug group compared to the placebo. } \\
\text { It has been observed that daily consumption of the CM } \\
\text { extract improves glycemic control in adults with type } \\
2 \text { diabetes. }\end{array}$ & \\
\hline & Fruits & $\begin{array}{l}\text { In pre-diabetic state of animals, it was found an } \\
\text { important decrease of glucose level after the oral } \\
\text { implementation of CM in dose of } 1000 \mathrm{mg} / \mathrm{kg} \mathrm{bw} \text { and } \\
\text { significant limitation of water intake. It is concluded } \\
\text { that if higher doses of CM are consumed regularly in } \\
\text { young animals, diabetic symptoms can be prevented. }\end{array}$ & (36) \\
\hline
\end{tabular}


Table 2B. Beneficial effects of different parts of Cornelian cherry

\begin{tabular}{|c|c|c|c|}
\hline \multirow[t]{4}{*}{$\begin{array}{l}\text { Cytotoxic and } \\
\text { Anticancer }\end{array}$} & Leaves & $\begin{array}{l}\text { Showed important cytotoxic effect against human breast } \\
\text { cancer cells. After treatment of } 72 \mathrm{~h} \text {, it was reduced the } \\
\text { survival of cells to } 11.1 \% \text { (at a dose of } 750 \mu \mathrm{g} / \mathrm{mL} \text { ). It is } \\
\text { stated that this effect is related to tannins and total } \\
\text { polyphenols in leaves. }\end{array}$ & (37) \\
\hline & Fruits & $\begin{array}{l}\text { Exhibited important cytotoxic effect against different tumor } \\
\text { cells (prostate adenocarcinoma, ovarian cancer, breast } \\
\text { adenocarcinoma and lung non small cell cancer cells by } \\
\text { growing inhibition of } 80.3 \%, 82.2 \%, 79.4 \% \text {, and } 78.2 \% \\
\text { respectively). }\end{array}$ & (38) \\
\hline & Fruits & $\begin{array}{l}\text { Showed anticancer effect against liver cancer and breast } \\
\text { cancer cells. It was observed that the cytotoxic effect of } \\
\text { unripe fruit was higher than that of ripe fruit. }\end{array}$ & (39) \\
\hline & Fruits & $\begin{array}{l}\text { The two forms of CM extract (free CM extract and } \\
\text { encapsulated into enteric coated nanocarriers) were studied. } \\
\text { It was determined that the encapsulated CM extract } \\
\text { effectively preserved the antioxidant activity and increased } \\
\text { the anticancer effect. }\end{array}$ & (40) \\
\hline \multirow[t]{8}{*}{ Protective } & Fruits & $\begin{array}{l}\text { Demonstrated cardioprotective effect by enhancing } \\
\text { myocardial endogenous antioxidant enzymes (glutathione } \\
\text { peroxidase (GPx), superoxide dismutase (SOD), catalase } \\
\text { (CAT)), lowering the high levels of myocardial lipid } \\
\text { peroxides, serum creatine kinase, serum lactate } \\
\text { dehydrogenase and fixing myocardial damage. }\end{array}$ & (41) \\
\hline & Leaves & $\begin{array}{l}\text { Decreased the lipid peroxidation products grades to 50.04\% } \\
\text { and showed important radioprotective effect. }\end{array}$ & (42) \\
\hline & Fruits & $\begin{array}{l}\text { Decreased the oxidative stress caused by methotrexate and } \\
\text { exhibited significant dose dependent preventive effect of the } \\
\text { sperms. Reported to have a similar effect to vitamin E. }\end{array}$ & (43) \\
\hline & Fruits & $\begin{array}{l}\text { Showed a protective effect on brain tissue by decreasing the } \\
\text { levels of protein carbonyl groups and thiol groups in plasma } \\
\text { and brain tissue and improving the activity of paraoxonase } \\
\text { enzyme. Also improved the activity of catalase enzyme in } \\
\text { brain tissue and showed preventive effect to the nervous } \\
\text { system from oxidative stress. }\end{array}$ & (44) \\
\hline & Fruits & $\begin{array}{l}\text { At the tested doses the CM extract improved the levels of } \\
\text { serum antioxidant enzymes and decreased the levels of urea, } \\
\text { uric acid, serum creatinine and showed renal protective } \\
\text { effect. }\end{array}$ & (45) \\
\hline & Fruits & $\begin{array}{l}\text { Increased the levels of antioxidant enzymes, decreased the } \\
\text { elevated malondialdehyde (MDA) and showed important } \\
\text { hepatoprotective effect. Also normalized the toxin-induced } \\
\text { hepatic lesions. }\end{array}$ & (46) \\
\hline & Fruits & $\begin{array}{l}\text { Showed hepatoprotective effect by reducing the activity of, } \\
\text { ALT, ALP, AST, Lactate dehydrogenase (LDH) and level of } \\
\text { direct bilirubin, MDA. }\end{array}$ & (47) \\
\hline & Fruits & $\begin{array}{l}\text { Showed protective effect of nervous system. It was stated } \\
\text { that CM flavonoids increased memory retention and can be } \\
\text { used in the treatment of Alzheimer's disease. }\end{array}$ & (48) \\
\hline \multirow[t]{2}{*}{ Other } & Fruits & $\begin{array}{l}\text { Ethnomedical use of CM in the treatment of ulcerative colitis } \\
\text { has been verified. }\end{array}$ & (49) \\
\hline & Fruits & $\begin{array}{l}\text { The extracts from fruits of CM showed important anti- } \\
\text { amylase and anti-lipase effect. Therefore, CM can be } \\
\text { regarded as effective inhibitors of digestive enzymes } \\
\text { involved in the prevention or control of diseases associated } \\
\text { with hyperlipidemia. }\end{array}$ & (50) \\
\hline
\end{tabular}




\section{Health benefits}

Since millennia, Cornelian cherry fruit, leaves and flowers are widely used in Caucasia and Central Asia as blood clotting as fruit and for the treatments of sore throat, anemia chickenpox, rachitis, and kidney-liver disorders $(23,24)$. It is also used as an ingredient in melatonin-rich medicines since it contains a higher level of melatonin. It has antipyretic and diarrheal effects, and the juice, sherbet or compote helps for the treatment of kidney stone diseases by increasing the amount of acid in the urine (25). This fruit improves kidney and liver functions, displays neuroprotective and anti-aging effects and contributes to restoring memory and motor skills. Furthermore, the fruit has positive effects on human skin and is used in the cosmetic industry in Europe. In addition, it is used as anti-bleeding agents (25).

The health benefits of different parts of Cornelian cherry are given in Table 2. This fruit is used depending on the countries' traditions. In Serbia, Cornelian cherry is employed as a preventive and curative remedy for the treatments of intestinal diseases, diarrhea and anemia as well as to booster the immune system (26), while it is applied in the treatment of digestive disorders and hemorrhoids in Turkey and Azerbaijan (23,27). In Caucasian countries, seed oil and fresh fruits are used as cures of stomach ulcers, wounds, and colitis (24). It has been reported that fruits are used in traditional medicine as cures of intestinal inflammation, diarrhea, malaria, kidney stones, fever, urinary tract infections, cancer and sunstroke in Iran (18). Cornelian cherry is employed in the traditional medicine for the treatment of intestinal inflammation and digestive disorders and also the cosmetics industry in Italy (28). Cornelian cherry is also used to regulate kidney functions and to treat diabetes in China (29). In addition, it is commonly used in Greece to prevent gout, anemia and skin diseases as well as joint pain, metabolism disorders and tuberculosis (30).

\section{Conclusion}

Cornelian cherry is found wild or grown in many Asian and European countries. It is widely used since the positive effects on health are well-known. It has widespread uses in both gastronomy and traditional medicine. The Cornelian cherry produced in Turkey is rich in vitamins and minerals and have important antioxidant compounds. The fruit is considered as a valuable nutritional supplement thanks to the richness in flavonoids, carotenoids, anthocyanins, iridoids, vitamins, phenolic acids, pectins, tannins, minerals and sugars. It is used in the treatment of many diseases like obesity, diabetes, cancer, hypercholesterolemia, digestive system diseases, liver and kidney disorders. Although the action mechanism of this fruit on the mentioned diseases is not clearly determined, it is well-known that most of these diseases are caused by oxidative stress. The clinical studies on patient groups should be completed on the plants rich in bioactive components like Cornelian cherry used in the prevention and treatment of illnesses. Furthermore, new studies are needed to discover the unknown effects on health and to review the known effects.

Ethics Committee Approval: Ethics committee approval is not required for this study.

Peer-review: Externally peer-reviewed.

Author Contributions: Concept: Z.K, I.K, Design: Z.K, I.K, Literature Search: Z.K, I.K, Data Collection and Processing: Z.K, I.K, Analysis and/or Interpretation: Z.K, I.K, Writing: Z. K, I. K,

Conflict of Interest: No conflict of interest was declared by the authors.

Financial Disclosure: The authors declared that this study hasn't received no financial support.

\section{References}

1. Tural S, Koca I. Physico-chemical and antioxidant properties of Cornelian cherry fruits (Cornus mas L.) grown in Turkey. Sci Hortic (Amsterdam). 2008;116(4):362-366.

https://doi.org/10.1016/j.scienta.2008.02.003.

2. Benzie IFF. Evolution of dietary antioxidants. Comp Biochem Physiol Part A Mol Integr Physiol. 2003;136(1):113-126. https://doi.org/10.1016/S1095-6433(02)00368-9.

3. Pisoschi AM, Pop A, Iordache F, Stanca L, Predoi G, Serban AI. Oxidative stress mitigation by antioxidants - An overview on their chemistry and influences on health status. Eur J Med Chem. 2021;209:112891. https://doi.org/10.1016/j.ejmech.2020.112891.

4. Seeram NP, Schutzki R, Chandra A, Nair MG. Characterization, Quantification, and Bioactivities of Anthocyanins in Cornus Species. J Agric Food Chem. 2002;50(9):2519-2523. https://doi.org/10.1021/jf0115903.

5. Ercişli S. Cornelian cherry Germplasm Resources of Turkey. J Fruit Ornam Plant Res. 2004;12:8792.

6. Klimenko S. The Cornelian cherry (Cornus mas L.): collection, preservation, and utilization of genetic resources. J Fruit Ornam Plant Res. 2004;12:93-98. 
7. Wyndham R. Cranberry juice and urinary tract infections. Med Today. 2006;7(5):72-73.

8. Badalica-Petrescu M, Dragan S, Ranga F, Fetea F, Socaciu C. Comparative HPLC-DAD-ESI(+)MS Fingerprint and Quantification of Phenolic and Flavonoid Composition of Aqueous Leaf Extracts of Cornus mas and Crataegus monogyna, in Relation to Their Cardiotonic Potential. Not Bot Horti Agrobot Cluj-Napoca. 2014;42(1):9-18. https://doi.org/10.15835/nbha4219270.

9. Drkenda P, Spahić A, Begić-Akagić A, vd. Pomological characteristics of some autochthonous genotypes of Cornelian cherry (Cornus mas L.) in Bosnia and Herzegovina. Erwerbs-obstbau. 2014;56(2):59-66.

10.Milenković-Anđelković AS, Anđelković MZ, Radovanović AN, Radovanović BC, Nikolić V. Phenol composition, DPPH radical scavenging and antimicrobial activity of Cornelian cherry (Cornus mas) fruit and leaf extracts. Hem Ind. 2015;69(4):331-337.

11.Pawlowska AM, Camangi F, Braca A. Qualiquantitative analysis of flavonoids of Cornus mas L.(Cornaceae) fruits. Food Chem. 2010;119(3):1257-1261.

12.Rudrapaul P, Kyriakopoulos AM, De UC, Zoumpourlis V, Dinda B. New flavonoids from the fruits of Cornus mas, Cornaceae. Phytochem Lett. 2015;11:292-295. https://doi.org/10.1016/j.phytol.2015.01.011.

13.Sozański T, Kucharska AZ, Szumny A, vd. The protective effect of the Cornus mas fruits (cornelian cherry) on hypertriglyceridemia and atherosclerosis through PPAR $\alpha$ activation in hypercholesterolemic rabbits. Phytomedicine. 2014;21(13):1774-1784. https://doi.org/10.1016/j.phymed.2014.09.005.

14.Behrangi N, Ghafoori H, Farahmand Z, Khani EM, Sanati MH. Comparison among Cornelian cherry and \&lt;i\&gt;Prunus cerasus\&lt;/i\&gt; According to Phenolic Content and Antioxidant Capacity by Three Various Methods of Extraction. Food Nutr Sci. 2015;06(12):1166-1173. https://doi.org/10.4236/fns.2015.612122.

15.Krivoruchko E V. Carboxylic Acids from Cornus mas. Chem Nat Compd. 2014;50(1):112-113. https://doi.org/10.1007/s10600-014-0879-y.

16.Szumny D, Sozański T, Kucharska AZ, vd. Application of Cornelian cherry iridoidpolyphenolic fraction and loganic acid to reduce intraocular pressure. Evidence-Based Complement Altern Med. 2015;2015.
17.Horváth G, Turcsi E, Molnár P, Szabó LG, Deli J. Isolation and identification of carotenoids in the fruit of Cornelian cherry (Cornus mas L.). Planta Med. 2007;73(09):P_286.

18.Zargari A. Iranian medicinal plants. Tehran Tehran Univ Publ. 1997.

19.PANTELIDIS G, VASILAKAKIS M, MANGANARIS G, DIAMANTIDIS G. Antioxidant capacity, phenol, anthocyanin and ascorbic acid contents in raspberries, blackberries, red currants, gooseberries and Cornelian cherries. Food Chem. 2007;102(3):777-783. https://doi.org/10.1016/j.foodchem.2006.06.021.

20.Popović BM, Štajner D, Slavko K, Sandra B. Antioxidant capacity of Cornelian cherry (Cornus mas L.) - Comparison between permanganate reducing antioxidant capacity and other antioxidant methods. Food Chem. 2012;134(2):734-741.

https://doi.org/10.1016/j.foodchem.2012.02.170.

21.Stankovic MS, Zia-Ul-Haq M, Bojovic BM, Topuzovic MD. Total phenolics, flavonoid content and antioxidant power of leaf, flower and fruits from Cornelian cherry (Cornus mas L.). Bulg J Agric Sci. 2014;20(2014):358-363.

22.Demir F, Hakki Kalyoncu İ. Some nutritional, pomological and physical properties of Cornelian cherry (Cornus mas L.). J Food Eng. 2003;60(3):335-341.

https://doi.org/https://doi.org/10.1016/S02608774(03)00056-6.

23. Dinda B, Kyriakopoulos AM, Dinda S, vd. Cornus mas L. (cornelian cherry), an important European and Asian traditional food and medicine: Ethnomedicine, phytochemistry and pharmacology for its commercial utilization in drug industry. J Ethnopharmacol. 2016;193:670690. https://doi.org/10.1016/j.jep.2016.09.042.

24.Lewis WH, Elvin-Lewis MPF. Medical botany: plants affecting human health. John Wiley \& Sons; 2003.

25.Polatoğlu B, Beşe AV. Sun Drying of Cornelian cherry Fruits (Cornus mas L.). Erzincan Univ J Sci Technol. 2017;10(1):68-77. https://doi.org/10.18185/erzifbed.289008.

26.Zlatković BK, Bogosavljević SS, Radivojević AR, Pavlović MA. Traditional use of the native medicinal plant resource of Mt. Rtanj (Eastern Serbia): Ethnobotanical evaluation and comparison. J Ethnopharmacol. 2014;151(1):704713.

27.Celik S, Bakırcı I, Şat IG. Physicochemical and organoleptic properties of yogurt with Cornelian cherry paste. Int J Food Prop. 2006;9(3):401-408. 
28.Egea T, Signorini MA, Bruschi P, vd. Spirits and liqueurs in European traditional medicine: Their history and ethnobotany in Tuscany and Bologna (Italy). J Ethnopharmacol. 2015;175:241-255.

29.Hsu P-C, Tsai Y-T, Lai J-N, Wu C-T, Lin S-K, Huang C-Y. Integrating traditional Chinese medicine healthcare into diabetes care by reducing the risk of developing kidney failure among type 2 diabetic patients: a population-based case control study. J Ethnopharmacol. 2014;156:358 364.

30.Reich L. Cornelian cherry from the shores of Ancient Greece. Mag Arnold Arbor. 1996;56:2-7.

31. Martinović A, Cavoski I. The exploitation of Cornelian cherry (Cornus mas L.) cultivars and genotypes from Montenegro as a source of natural bioactive compounds. Food Chem. 2020;318:126549.

https://doi.org/https://doi.org/10.1016/j.foodchem .2020 .126549 .

32.Kyriakopoulos AM, Dinda B. Cornus mas (Linnaeus) Novel Devised Medicinal Preparations: Bactericidal Effect against Staphylococcus aureus and Pseudomonas aeruginosa. Molecules. 2015;20(6):11202-11218. https://doi.org/10.3390/molecules200611202.

33. Yigit D. Antimicrobial and Antioxidant Evaluation of Fruit Extract from Cornus mas L. Aksaray Univ J Sci Eng. 2018;2(1):41-51. https://doi.org/10.29002/asujse.329856.

34. Asgary S, Rafieian-Kopaei M, Shamsi F, Najafi S, Sahebkar A. Biochemical and histopathological study of the anti-hyperglycemic and antihyperlipidemic effects of Cornelian cherry (Cornus mas L.) in alloxan-induced diabetic rats. J Complement Integr Med. 2014;11(2):63-69. https://doi.org/https://doi.org/10.1515/jcim-20130022.

35.Soltani R, Gorji A, Asgary S, Sarrafzadegan N, Siavash M. Evaluation of the Effects of Cornus mas L. Fruit Extract on Glycemic Control and Insulin Level in Type 2 Diabetic Adult Patients: A Randomized Double-Blind Placebo-Controlled Clinical Trial. Eddouks M, editör. EvidenceBased Complement Altern Med. 2015;2015:740954. https://doi.org/10.1155/2015/740954.

36. Capcarova M, Kalafova A, Schwarzova M, vd. Cornelian cherry fruit improves glycaemia and manifestations of diabetes in obese Zucker diabetic fatty rats. Res Vet Sci. 2019;126:118123.

https://doi.org/https://doi.org/10.1016/j.rvsc.2019 .08 .024 .
37.Forman V, Haladová M, Grančai D, Ficková M. Antiproliferative Activities of Water Infusions from Leaves of Five Cornus L. Species. Molecules. 2015;20(12):22546-22552. https://doi.org/10.3390/molecules201219786.

38. Yousefi B, Abasi M, Abbasi MM, JahanbanEsfahlan R. Anti-Proliferative Properties of Cornus mass Fruit in Different Human Cancer Cells. Asian Pac J Cancer Prev. 2015;16(14):5727-5731. https://doi.org/10.7314/apjcp.2015.16.14.5727.

39.Rezaei F, Shokrzadeh M, Majd A, Nezhadsattari T. Cytotoxic effect of hydroalcoholic extract of Cornus Mas L. fruit on MCF7, HepG2 and CHO cell lineby MTT Assay. J Maz Univ Med Sci. 2014;24(113):130-138.

40.Radbeh Z, Asefi N, Hamishehkar H, Roufegarinejad L, Pezeshki A. Novel carriers ensuring enhanced anti-cancer activity of Cornus mas (cornelian cherry) bioactive compounds. Biomed Pharmacother. 2020;125:109906. https://doi.org/https://doi.org/10.1016/j.biopha.20 20.109906.

41.Eshaghi M, Zare S, Banihabib N, Nejati V, Farokhi F, Mikaili P. Cardioprotective effect of Cornus mas fruit extract against carbon tetrachloride induced-cardiotoxicity in albino rats. J Basic Appl Sci Res. 2012;2(11):11106-11114.

42.Leskovac A, Joksic G, Jankovic T, Savikin K, Menkovic N. Radioprotective properties of the phytochemically characterized extracts of Crataegus monogyna, Cornus mas and Gentianella austriaca on human lymphocytes in vitro. Planta Med. 2007;73(11):1169-1175. https://doi.org/10.1055/s-2007-981586.

43.Zarei L, Sadrkhanlou R, Shahrooz R, Malekinejad $\mathrm{H}$, Eilkhanizadeh B, Ahmadi A. Protective effects of vitamin $\mathrm{E}$ and Cornus mas fruit extract on methotrexate-induced cytotoxicity in sperms of adult mice. Vet Res forum an Int Q J. 2014;5(1):21-27.

44.Francik R, Kryczyk J, Krö̈niak M, Berköz M, Sanocka I, Francik S. The neuroprotective effect of Cornus mas on brain tissue of wistar rats. Sci World J. 2014;2014. https://doi.org/10.1155/2014/847368.

45.Es Haghi M, Dehghan G, Banihabib N, Zare S, Mikaili P, Panahi F. Protective effects of Cornus mas fruit extract on carbon tetrachloride induced nephrotoxicity in rats. Indian $\mathbf{J}$ Nephrol. 2014;24(5):291-296. https://doi.org/10.4103/0971-4065.133000. 
46. Somi MH, Banihabib N, Dehghan G, Es. Haghi M, Panahi F. Hepatoprotective Effect of Cornus mas Fruits Extract Against Carbon TetrachlorideInduced Hepatic Damage in Male Albino Rats. Thrita. 2014;3(2):1-5. https://doi.org/10.5812/thrita.17624.

47.Saei H, Hatami H, Azarmi M, Dehghan G. Hepatoprotective effect of cornus mas fruits extract on serum biomarkers in methotrexateinduced liver injury in male rats. 2016;2016:9198.

48.Darbandi N, Hashemi A, Noori M, Momeni HR. Effect of Cornus mas fruit flavonoids on memory retention, level of plasma glucose and lipids in an intracerebroventricular streptozotocin-induced experimental Alzheimer's disease model in Wistar rats. Environ Exp Biol. 2016;14(3):113-120. https://doi.org/10.22364/eeb.14.16.

49. Süntar I, Cevik CK, Çeribaşı AO, Gökbulut A. Healing effects of Cornus mas L. in experimentally induced ulcerative colitis in rats: From ethnobotany to pharmacology. J Ethnopharmacol. 2020;248:112322. https://doi.org/10.1016/j.jep.2019.112322.

50.Świerczewska A, Buchholz T, Melzig MF, Czerwińska ME. In vitro $\alpha$-amylase and pancreatic lipase inhibitory activity of Cornus mas L. and Cornus alba L. fruit extracts. J Food Drug Anal. 2019;27(1):249-258. https://doi.org/10.1016/j.jfda.2018.06.005. 